\title{
Towards Understanding the Status of the Dual in Pre-Islamic Arabic
}

\author{
MuHAmmad AL-Sharkawi (Wayne State University, Detroit)
}

\begin{abstract}
This article suggests that the dual suffix in pre-Islamic Arabic did not differentiate for case. Tamīm, one of the most trustworthy pre-Islamic dialects, treated the dual suffix invariably although it had a full case system. There are also tokens of the same invariable treatment in the Qur'ān. The article proposes that the suffix long vowel variation due to the phenomenon of imāla makes the formal origin of the invariable dual suffix difficult to ascribe to the East and Northwest Semitic oblique dual allomorph.
\end{abstract}

Keywords: Dual, pre-Islamic Arabic, 'imāla, Classical Arabic, vowel harmony.

\section{Introduction}

This article discusses data on the dual suffix in pre-Islamic dialects from medieval Arab grammarians and manuals of qiräa $\bar{a} t$ to suggest that the status of the dual suffix in the preIslamic Arabic linguistic situation was unique among the Semitic languages. ${ }^{1}$ The article does not, however, seek to take a comparative Semitic framework. It rather seeks to discuss the dual suffix behavior on the eve of the Arab conquests and probably immediately thereafter. Although attempts to understand particular structural concepts of pre-Islamic Arabic are forthcoming, the formal, functional and semantic shape of the dual system remains to be studied in detail. In addition, despite the limited and sporadic data about the morphological and syntactic aspects of pre-Islamic Arabic, ${ }^{2}$ the dual suffix ${ }^{3}$ is one of the features of pre-Islamic Arabic dialects that can shed light on both the position of grammatical case ${ }^{4}$ in the Arabic dialects in the peninsula, and how it came to be standardized after the emergence of Islam.

It has been suggested before that the formal and functional differences between Classical Arabic and Modern Standard Arabic on the one hand and the modern dialects of Arabic

1 For a study of the dual in Semitic in general, see FonTINOY 1969. For some observations on the dual in pre-Islamic Arabia, cf. RABIN 1951: 56f. and 156f.

2 For the definition of pre-Islamic Arabic, see AL-SHARKAWI 2008.

3 For a general idea about the dual system in its morphological and syntactic aspects in Arabic, see ALSHARKAWI 2013.

4 On grammatical case in Arabic, see LeTourneau 2006.

Journal of Arabic and Islamic Studies • 15 (2015): 59-72 
on the other hand as far as the dual paradigm is concerned may have happened due to several favorable internal and external ecological factors that started to work and take effect during the times of the early Arab conquests in the conquered territories outside the Arabian Peninsula. It has also been suggested that despite the formal and functional differences, pseudo-duals in all the modern dialects indicate that the ancestors of modern dialects and the ancestors of Classical Arabic must have shared a common origin since the two types of dialects behave identically in particular noun categories when the dual noun comes as a first word in a possessive structure. However, few studies addressed the issue of the dual suffix and paradigm in pre-Islamic Arabic and its relationship to Classical Arabic and its Semitic context, and also its developmental behavior during this critical period of the Arabic language. ${ }^{5}$ This article is an attempt to address the issue of the morphological dual ending in the pre-Islamic Arabic dialects by simply discussing its formal features in so far as the issue of its case marking is concerned. The data that I will use for the purpose of this discussion is admittedly scanty. It comes as single token examples that later grammarians copy and repeat from earlier ones. In addition, some of the data is indirect, such as testimonials, which will be relied on for lack of direct linguistic tokens.

According to the theoretical grammatical concept of $s a m \bar{a}^{`} /$ naql 'data transmission', data from pre-Islamic dialects, poetry, speech of the Prophet and of course the Qur'ann are all trustworthy and eloquent. These data sources reflect a formal picture of the dual suffix that is at once contradictory with the dual suffix in Classical Arabic and indicative of an arbitrary standardization of the that suffix as I will suggest in this article. It is very interesting that data on pre-Islamic dialects of Arabic either reflect an invariable treatment of the dual suffix, as in Hijāz and Tamīm, or are missing all together as in Qays and 'Asad. It is also interesting that some pre-Islamic poetry, sayings of the Prophet and the Qur'ān exhibit traces of this treatment. But Classical Arabic clearly differentiates between a dual suffix morpheme in the nominative and another dual suffix morpheme in the accusative and genitive. The accusative and genitive nouns are not marked with two formally distinct allomorphs of the dual suffix, which indicates a typical Semitic case differentiation.

In classical Arabic, and indeed in other case-bearing Semitic languages, the dual noun suffix is both a number suffix and a case suffix. The noun is marked in the nominative by an $-\bar{a} n$ suffix at the end of masculine and feminine nouns. In the accusative and genitive nouns the dual suffix marker is -ayn. Here lies one important part of the discussion of this article. Both of these suffixes end with a short vowel $-i$. Here lies another part of the issue. The rest of the issue lies in the quality of the vowel part of the suffix. Arab grammarians and qir $\bar{a}$ 'at readers give a description of that vowel quality and length that may help us understand the dual suffix in pre-Islamic Arabic and indeed in Classical Arabic. The argument this article seeks to make is that the difference between the two dual suffix morphemes in pre-Islamic dialects may not have been a difference in case. Taking the $-\bar{a} n$ to be a nominative suffix and -ayn to be a genitive and accusative suffix can be a reconstruction of the grammarians as late as the 8th century, since the dual suffix behavior in the best dialects in terms of case from the point of view of medieval Arab grammarians does not confirm to the dual norms of Classical Arabic.

\footnotetext{
5 AL-SHARKAWI 2013.
} 
This article uses the grammarians' treatment of the nominal dual suffix ending and data on 'imāla to propose a suggestion to the developmental status of both the dual suffix and grammatical case in pre-Islamic dialects, pre-Classical and Classical Arabic. ${ }^{7}$ The shape and developmental and functional status of the dual paradigm as a morpho-syntactic system in pre-Islamic Arabic and in Classical Arabic are, however, yet to be understood, but this is not the focus here. ${ }^{8}$ There is simply not enough data from authentic actual use and data from the kaläm al-'arab 'speech of the Arabs', pre-Islamic poetry or the Qur'ān.

\section{The Argument}

To demonstrate the uniqueness of the dual morpheme in pre-Islamic Arabic I will briefly discuss the status of the nominal dual in proto-Semitic and various Semitic languages including Classical Arabic. There is enough constructed data from proto-Semitic and its varieties to indicate that as far as nouns are concerned there is always a case marking distinction between a nominative dual allomorph and an accusative and genitive dual allomorph in all the languages that mark the noun class for case. Although the status of the dual in other word classes differs in these languages greatly, they all agree on either declining the dual suffix for case when they have case or use an invariable dual suffix when they do not have case. It seems that the Najdi dialects of Arabic broke this pattern They had a dual suffix morpheme but did not decline it for case although these dialects realized case. The single dual suffix morpheme, in addition, seems to have been common among Western Hijāzi, Southern Yemeni and Najdi conservative dialects that the Arab grammarians trusted for data on case. The formal origin of the single dual morpheme is difficult to determine especially in Tamim, because of the varying sound qualities the grammarians collectively designate 'imāla. To make this point I will use data from the Qur'ān, manuals of qirāa'a ${ }^{9}$ and books of Arabic grammar.

To demonstrate the relevance of Tamim to this discussion, I will talk briefly about two basic relevant governing theoretical concepts in the medieval Arabic grammars that have to do with data collection and trustworthiness in general and grammatical case in particular. The first deals with the grammarians' perception of the distribution of case among Arab tribal dialects before Islam and the second deals with the best case-related data source among these tribes. My understanding is that these two points state obviously that the Arab grammarians believed that all dialects had case, but some dialects were more trust-worth than others as sources of case data. Features of these dialects were used both to explain and exemplify rules and to build rules on. In section two, I will discuss the status of the dual suffix in these source dialects and also in the other less trusted tribal dialects. The purpose of this section is to show that there was no pre-Islamic Arabic dialect, conservative or otherwise, that alternated between two forms of the same dual suffix. In section three, I will discuss the non-confirmatory use of the dual suffix in both the Qur'ān and Hadī $\underline{t}$ in order

6 For a clear English description of the phenomenon of 'imäla, see LEVIN 2007.

7 For definition and information on pre-Classical and Classical Arabic, see FISCHER 2006.

8 These issues have been referred to in RETSÖ 2006: $25 \mathrm{f}$.

9 For a general description and brief history of the literature of qirāa $\bar{a} t$, see SHAH 2009. 
to show that these founding texts show remnants of the dialectal case-less treatment of the dual suffix. In the last section I will discuss 'imäla in the pre-Islamic dialects as the source of the misleading forms of the suffix in these dialects.

\section{The Dual Morpheme in Semitic}

There are two types of behavior for the dual suffix on nouns in the Semitic languages. In those languages that have a case system, the treatment of the dual is diptotic. There is one nominal allomorph and another oblique allomorph for the genitive and accusative cases together. ${ }^{10}$ Old Akkadian, Palaeosyrian, Old Babylonian, Ugaritic and preClassical/ Classical Arabic belong to this group of languages. The other type of behavior is found in the languages that have lost the case system. In these languages, a reflex of the oblique case is believed to have been generalized for the nominative as well. ${ }^{11}$ Hebrew, Phoenician, Modern South Arabian, and neo-/modern Arabic dialects belong to this second group of languages. The data we have so far does not attest to any of these languages having the case-declining and case-insensitive dual morphemes at the same time. Pre-Islamic Arabic has the types of suffixes at the same time. As we will see in the following section this loss of case-distinguishing dual suffix in pre-Islamic Arabic dialects probably preceded the loss of the short vowel case markers on the singular nouns. Or, as the data on 'imāla may show, the loss of dual case distinction may have been caused by non-syntactic sound features.

In the following table, I will show the dual suffix distribution in different Semitic languages: ${ }^{12}$

Table 1 Case-Marking Dual Suffix

\begin{tabular}{lll}
\hline Language & Nominative suffix & Oblique Suffix \\
\hline Old Akkadian & $-\bar{a} n$ & $-\bar{l} n$ \\
Old Babylonian & $-\bar{a} n$ & $-\overline{-} n$ \\
Ugaritic & $-\bar{A} m A$ & $-\bar{E} m A$ \\
Classical Arabic & $-\bar{a} n i$ & $-a y n i$ \\
\hline
\end{tabular}

This sampling of Semitic languages shows the similarity of behavior in all the geographical areas of the family. Akkadian and Babylonian are from the Eastern Semitic branch while Ugaritic is a North Semitic language and Arabic is a North Arabian. In addition, all these

10 See LIPIŃSKI 1997: 236.

11 See LIPIŃSKI 1997: 237.

12 This table is excerpted from BENNETT 1998: 75-93. 
languages are also case-baring. ${ }^{13}$ In the Semitic languages that lost the case system such as Hebrew $^{14}$ there is a single dual morpheme that does not bear case:

Table 2 Dual Suffix in Non-Case Bearing Languages

\begin{tabular}{ll}
\hline Language & The Dual Suffix \\
\hline Hebrew & -ayim \\
Najdi Arabic & -ayn/-ēn/-ān \\
\hline
\end{tabular}

Despite the formal similarity with Hebrew, we know from testimonials of medieval Arab grammarians that Najdi dialects in general and those of Tamim in particular have given the dual the same oblique ending. This contradicts the fact that Tamim is one of the best three dialects in Arabic in realizing the case system in its full Semitic triptotic shape.

\section{Grammarians and Case}

As-sama $\bar{a}$ ' hearing' or an-naql 'transmission' is one of the fundamental underlying concepts of data collection in traditional Arabic grammar. It is essentially the verified data that comes from the speech of those whose eloquence is trustworthy. It includes the word of God, the speech of his prophet, the speech of the Arabs before his prophecy, during his time and after his death in prose and poetry and from a Muslim or a käfir (al-Iqtirāh, 74). This text is a statement that what comes in these sources of data is both correct and acceptable. Data on duals can be used to develop rules or to test them. Both the Qur'ān and Hadīt do not need definition. The speech of the trustworthy Arabs is not as clear. Now, who are trustworthy eloquent Arabs?

To address this issue in a short and direct manner, I would like to discuss a text ascribed to al-Farābī in his al-'alfäz wa-l-ḥurüf (quoted in as-Suyūṭị, al-Iqtirăh p. 19-20 and alMuzhir, I: 211-212), in which he stated which tribes to take data and examples from and which not, and why. Arabic data in general, and grammatical case marking in particular, alFarābī states, must be taken from the tribes of 'Asad, Tamīm, and Qays. These three tribes are the source of most of the data on case and morphology, and they also are to be trusted for the strange and irregular. In addition to these three full tribes, there are parts of other tribes that are as trustworthy as these three, albeit to a lesser degree. They are parts of Hudayl, parts of Kināna and parts of Tayyi'. As a rule, no data is trustworthy when and if it is taken from a settled tribe or from a clan that lived in the parts bordering other nations. The only reason given to this wide range of exclusion is the potential for a foreign influence on the excluded tribes, which are the overwhelming majority of the Arab tribes. This cautionary note seems to be both anticipatory and not directed to case related data specifically. I will come back to this statement once more in the discussion section.

13 See HaSSELBACH 2013: 16.

14 See HaSSELBACH 2013: 33. 
If we take the previous testimony of the Arab grammarians and countless similar ones as essentially correct and indicative of the position of grammatical case in the pre-Islamic dialects, the main source of kaläm al-'arab, we can see that they believed that all the Arabs used grammatical case, but some of them used it better than others. Ibn Fāris makes grammatical case a distinctive structural feature of the Arabic dialects. He claims that case sets the dialects of the Arabs aside from other languages (aș-Șāhibī, 43). In addition, he quotes a long list of differences among the dialects in which (aș-Ṣāhịibì, 26) grammatical case is a feature that varies from a dialect to another. Although Ibn Fāris mentions this distinctive element vaguely, it seems that he does not see exceptions in use that he needed to explain away or justify.

'Abū Hayyān (al-Bahr al-Muḥit, VI: 255), in his discussion of the non-confirmatory use of the dual suffix in Q 20:63, mentions different tribes from different locations in the Arabian peninsula, both Bedouin and settled ones, that use case. From that distribution, one understands that case was a general mark of the pre-Islamic dialects. He mentions tribes from areas wide apart such as Zabīd, Murād, Kināna and Hamadān from the southwestern part of the peninsula. In discussing the same phenomenon, as-Suyūtī (Ham ‘ al-hawāmi`, I: 40) mentions case in Bakr and Rabī'a from Tamīm in the eastern part of the peninsula. From the above, we can understand that despite the dialectical differences, grammatical case was a structural feature of all the tribal dialects of Arabic. The best representative dialects that a grammarian can take data from concerning case are 'Asad, Qays, and Tamīm. In the following section, we will see the position of case on the dual suffix in one of these tribal dialect groups.

\section{The Dual Suffix}

In this section, I will present a summary of the data in medieval Arab grammars and qirāa $\bar{a} t$ manuals in so far as the dual suffix is concerned. I will discuss the dual suffix in 'Asad and Qays in very short terms, due to the lack of data on the subject. I will discuss data from Tamīm as the ideal grammatical case dialect to show that they did not use two allomorphs, one for the nominative dual noun and the other for the accusative and genitive duals. I will then discuss the dual suffix treatment in Hijāz and other less trusted dialects. This data will show that despite the grammarians' perception about dialects, both groups use a single dual suffix, albeit with different vowel. The data will also show that the final short vowels on the dual suffix in some of the dialects vary according to the position of the noun in the sentence. This kind of data may be suggestive of an earlier phase of Arabic where declining dual nouns for case happened by means of short final vowels at the end of the suffix. But due to the fixed vowel treatmenot of these short final vowels, declining dual nouns for case must have been an earlier stage in the development of the dual system in the pre-Islamic Arabic dialects.

An overview of the grammatical literature and manuals of qir $\bar{a} \bar{a} t$ shows that geographically speaking, the use of - $\bar{a} n$ - ('alif and $n \bar{u} n$ ) or 'ilzām al-mutnnā al-'alif fixed dual suffix was very widespread in the Arabian Peninsula. It was used in Bilhạrit Bin Ka ${ }^{c} b$ (Ibn Xālawayh, al-Huğğa, 96) of Tamīm in northeast Yemen (al-Hamadān̄i, Sifa, 102). It is also the only dual suffix in some parts of Bakr and Rabīa in Northeast Arabia. In Yemen it was 
the dual suffix in Zabīd, Xaț'am, Hamadān, Murād, and 'Uḍāā (al-Hamadānī, Șifa, 136). It was also the only suffix in Kināna, Banū al-Huğaym and Bil'ambar (al-Qalaqašandī, Nihāyat al-'arab, 42 and 68). It is interesting that these tribes belong to both of the two genealogical origins of the Arabs in general. Bilhārit Bin Ka'b, Zabīd, Xațam, Hamadān and Murād come from a Qaḥtāni/Yemeni origin (Ibn Ḥazm, Ğamhara, 405). Some of these tribes come from a northern 'Adnān̄i origin. They are Kināna, Banū al-Huğaym, Bakr, Bil'ambar and Rabīa. geographically, these tribes are distributed all over the peninsula. Those tribes who belong to a southern origin were situated in the southwest of the peninsula as a general rule, and extended to the northwest in Hijāz (al-Qalaqašandī, Subḥ, I: 320). As for the tribes who belong to a northern origin, they are situated in the Northeast as a general rule.

It is important to note here that, in addition to the wide geographical distribution of the single dual suffix treatment, many of the clans that do not decline the dual suffix for case are from Tamìm, one of the three model case-realizing tribes according to the Arab grammarians. As for the other two trust-worthy tribes, data on the long vowel treatment in Qays and 'Asad is not forthcoming. Medieval Arabic grammars, in addition, do not refer to any tribal dialects that may have used the two allomorphs in free variation. The data on Qays and 'Asad are not clear. The grammarians did not state if these two dialects used a single dual suffix allomorph or two allomorphs as did Classical Arabic later did. The same vagueness of idea about the dual suffix persists in the case of Hijāz. Geographically speaking, though, the dialects of northwest Yemen and of Kināna seem to have treated the dual suffix invariably (Ibn Hišām, Muginī, I:. 47-49). These are Hijāzi dialects. There is also one tradition ascribed to the prophet with invariable treatment of the dual suffix. We will discuss this tradition in the following section. However, apart from these circumstantial pieces of evidence, we have no more details on the dual in Hijāz.

But the fact that the invariable treatment is geographically wide-spread and far apart, and the fact that several Tamim dialects take part in this treatment are strong indications that pre-Islamic dialects did not decline dual nouns for case. It is also very interesting that the invariable treatment in this geographically wide area and originally different tribes is uniform: they all use the 'alif and nün for the dual suffix. It is, therefore, my assumption that understanding the sound quality of the 'alif is key to understanding the grammarians' later interpretation of this dual suffix as case-bearing. We will deal with this issue later in section 4 of this article. It is now worthwhile to refer to the invariable use of the dual suffix in other sources of the period to show that the Qur'ān and Hadīin, which are from a Hijāzi dialect origin, show remnants of invariable treatment.

\section{The Dual in the Other Sources of $a s-s a m \bar{a}^{c}$}

In this section, I will deal with tokens of data from other sources of $s a m \bar{a}^{c}$ that constitute good and trustworthy Arabic. The data here, though anecdotal, indicates that not only in the kaläm al-'arab 'speech of the Arabs' the dual suffix was sometimes treated invariably. That is to say, there was, at least before Sỉbawayh's career and impact, a potential acceptance for the single dual suffix; hence we can see remnants of this treatment despite the pervasive effect of standardization. There are many references to the treatment of the dual with an 
invariable 'alif. We will talk about the sound quality of this orthographic marker in the following section, but let us now focus on examples for invariable treatment. I will briefly discuss two examples from the Qur'ân and discuss one example from the Hadīt.

(1) Q 20:63 'inna hāạāni la-sāhirāni (Cairene edition: 'in hāạāni ....) ${ }^{15}$ 'certainly, the se wo are magicians'

All readers of the Qur'ann, with the sole recorded and very interesting exception of the Tamīmi reader 'Abū 'Amr Ibn al-'Alā', read this verse invariably with $h \bar{a} \underline{\underline{d}} \bar{a} n i$ in the nominative case despite the fact that it follows 'inna, which governs an accusative nominal head according to the rules of Classical Arabic. 'Abū 'Amr reads it with hädayni arguably bi-y $\bar{a}^{\prime}$ wa-nūn 'with $y \bar{a}$ ' and $n \bar{u} n$ ' in the proper accusative, although he belongs to a Tamīmi clan that theoretically treats the dual suffix invariably with an 'alif ('Abū Hayyān, al-Bahrr, VI: 255). This first example has to do with a noun in the subject position of the nominal sentence after 'inna. I will come back to this example once again later in this article, because it seems to be a key in our understanding of the long vowel sound quality.

(2) Q 18:80 'amma l-ġulāmu fa-kāna 'abawā-hu mu'mināni

(Cairene edition: ... mu'minayni)

'and as for the youth, his parents were believers'

This verse is read with either mu'minayni as proper Classical Arabic syntactic rules would have it because it is the predicate of a nominal sentence governed by kāna, or with mu'mināni as 'Abū Sa'īd al-Xudrī read it in opposition to the case rules of Classical Arabic and according to the dialect of Bilḥ̂̄rit ibn Ka'b of Tamīm ('Abū Ḥayyān, al-Baḥr, VI: 255).

The issue is not limited to the Qur'ānic readings of the Holy Book. There are some references in the compendia of Hadit to an invariable use by the Prophet of the dual suffix. There is a reference in the Sahīh of at-Tirmidī that there is a saying by the Prophet that uses an invariable dual ending with an 'alif, although the rules of Classical Arabic dictate a $y \bar{a}^{\prime}$ treatment because the noun is not in the subject position. The Prophet is reported to have said:

(3) lā witrāni fí l-layla 'no witr (additional voluntary prayer) at night'

In this statement, the dual noun witrān needs to be in the accusative, not in the nominative as stated in (3) above, because it is governed by la an-näfiya li-l-ğins 'no of absolute negation' as in the rules of Classical Arabic. Theoretically, its ending in Classical Arabic must be an -ayn and not an $-\bar{a} n$ suffix. All the previous examples, few as they are, include tokens in the accusative position, only none of them deals with nominal tokens in the nominative position. These examples are as important as they are limited and few in number.

15 For a discussion of this example in connection with the issue of 'in al-muxaffafa and al-lām al-färiqa, see Nebes 1985: 8.

$J A I S \bullet 15$ (2015): 59-72 


\section{'imāla and the Dual Suffix}

In this section, I will discuss 'imāla in the dialects of Tamīm in pre-Islamic times to suggest that the long vowel in the dual suffix could have exhibited different qualities according to the vowel and consonantal environments in its neighborhood. I will use the phonological and phonetic description of 'imāla in Owens (2006: 197ff) in order to make the claim that 'imāla took different sound qualities according to its environment that were later interpreted as case-relevant. There is a lot of confusion among the grammarians as to who of the Arabs used the phenomenon and who did not. Generally, only some of the Arabs tended towards 'imāla of $/ \overline{\mathrm{a}} />/ \overline{\mathrm{e}} /$. We know that - generally speaking - the region of Hijāz did not use it ('Abū Hayyān, al-Bahrr, I: 71), but realized the $/ \bar{a} />/ \overline{\mathbf{o}} /$ quality that the Arabs called tafxīm 'magnification" 16 ('Abū Hayyān, al-Baḥr, I: 59). Neither did Yemen use the phenomenon, although the tribes in the north east of Yemen did. However, the situation of 'imāla in Hijāz is not very clear, for it seems there are tribal dialects that did in fact use 'imāla instead of tafxìm. The 'Asad and Qays tribes of Najd also leaned in some of their clans towards 'imāla (Ibn Yaīš, Šarh al-mufașṣal, IX: 54). Among these Najdi tribes Tamīm, according to the Arab grammarians, was the group of dialects that used 'imāla consistently (Ibn al-Hāăib, Šarh aš-šăfiya, III: 4).

Now, what does 'imāla in relation to tafxìm mean? It is (1) iștilāhan taqrīb al-fatha

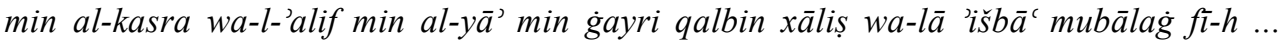
(2) hiya 'ibāra 'an an-nuṭ bi-l-'alif markaba 'alā fatha tuṣraf 'ilā l-kasra 'technically, it

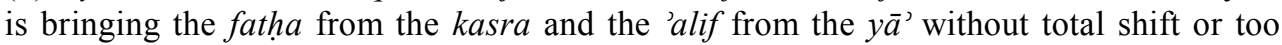
much blending. It is pronouncing the 'alif mounted on a fatha and moving towards the kasra' (aḍ-Dabbā', al-'Id $\bar{a}^{\prime} a, 28$ ). From (1) we can understand that 'imāla is a matter of approximation and fixing of the tongue positions. It constitutes a shift in the tongue position from a lower to a medium height to produce a vowel between the two qualities of tafxim and kasr. In (2), however, there is a sense of a glide from the position of tafxim towards the position of $y \bar{a}^{\text {s }}$ without reaching there quite, which may render a glide quality like /ay/. Owens (2006) explains some of the phonetic contexts of the glide quality.

Generally speaking, 'imāla is a change that happens to the long $/ \bar{a} /$ in the neighborhood of a short /i/ vowel in the previous or following syllable towards an /e/ like quality (Owens 2006: 197). This change happens in the medium or final parts of the word. From traditional Arab grammarians, one can understand 'imāla in two different phonetic descriptions. According to most grammarians, apart from Sībawayh, it is to be understood as a change from a long vowel to an off-glide /ai/. The grammarians describe the phenomenon as inclining the 'alif towards the $y \bar{a}$ ' (Ibn Ğinn̄̄, Sirr, I: 58 and Zamaxšarī, Mufașsal, 355). This definition means that one starts from the 'alif and moves to the $y \bar{a}$ '. While this understanding is plausible, Owens (2006: 200) finds it problematic. According to him, this understanding of 'imāla makes it identical to the already existing diphthong /ay/. As evidence, Owens declares that Sībawayh does not mention any similarity between the two sounds. In addition, after the discussion of 'imāla Sībawayh discusses a case in which some Qaysi Arabs change the final $-\bar{a}$ in some nouns such as hubla 'preg-

16 For the definition and more information on this sound quality in both consonants and vowels, see BAKALLA 2009: 421-424. 
nant' in pause positions into -ay to become hublay. Although this is a clear case of an off-glide, Sībawayh does not include it in his discussion of 'imāla. There is also a pronunciation of the same word that Sībawayh discusses in the chapters on 'imāla where the word ends with an on-glide -ie rather than an off glide (Owens 2006: 200-201).

Owens's (2006) analysis of Sỉbawayh adds more to the quality of this phenomenon. He suggests that 'imāla as intended by Sībawayh is actually an on-glide /ie/ rather than an off-glide. Sỉbawayh declared that $/ \overline{\mathrm{a}} /$ is inclined if it is followed by consonant with a kasra. This statement is made in the passive voice. Owens understands, and correctly so, that this statement shows that the tongue starts from the position of $/ \mathrm{i} /$ and moves towards /a/. This realization of 'imāla is attested in the Qur'ānic readings especially that of 'Abū 'Amr ibn al-'Alā' and al-Kisā'̄ (Owens 2006: 199). To prove that the tongue does not begin from the /a/ but from the $/ \mathrm{i} /$, Owens continues that guttural, $/ \mathrm{r} /$, and emphatic sound consonants and the neighborhood of $/ \mathrm{u} /$ or $/ \mathrm{a} /$ that have a lower tongue positions prohibit 'imāla, and keep $/ \bar{a} /$ as is, which indicates that the initial tongue position of the 'imāla is not low /a/ (Owens 2006: 201). Now, that said, we can say that $/ \bar{a} /$ tends to 'imāla unless prevented by one of the previous sounds (Corriente 1977: 22). These two descriptions of the 'imāla phenomenon take it towards glides. Textual descriptions, however, can indicate an additional sound quality.

Furthermore, Ibn Ya ī̌š in Šarh al-mufașṣal (vol. IX: 54) defines 'imāla in a different manner, one that betrays a long vowel rather than a glide. It is: 'udül bi-l-'alif 'an istiwā'i$h$ wa-ğunūh bi-hi 'ilā al-yā' fa-yașìr maxrağu-hu bayna maxrağ al-'alif al-mufaxxama wa bayna maxrağ al-yā' 'taking the alif away from its straight forward position towards the place of articulation of the $a l-y \bar{a}$, so its place of articulation is between that of the emphatic 'alif and that of the $y \bar{a}$ '. From this definition, we can see that Ibn Ya $\mathrm{Y}(\overline{\mathrm{s}}$ focuses on tongue movement rather than the vowel quality. According to him, the position of the tongue is hanging stable between the position of the $/ \bar{a} /$ and that of the $/ \overline{1} /$ and not the gliding between them. This medium position of the tongue articulates a possible long $/ \overline{\mathrm{e}} /-$ like vowel, and adds to the previous two qualities. Sībawayh (al-Kitāb, II: 259) gives us three phonetic contexts that we can use to corroborate this triple-quality analysis and from which we can understand that what is collectively termed 'imāla and differently defined can be interpreted as an on-glide /ai/, an off-glide /ia/ and a long front medium vowel /ē/.

First, according to Sībawayh, the /ā/ endures imāla when it precedes a short /i/, such as ' $\bar{a}$ bid and 'älim. In such environments, it is logical that the long /ā/ inclines towards the /i/ by the tongue rising to a higher front vowel position. This is the context of an offglide /ai/, where the tongue starts with the long low front $/ \bar{a} /$ and glides upwards in preparation for the short $/ \mathrm{i} /$.

(4) 'ābid > 'aibid (proper noun)

In this context, 'imāla comes in the first syllable or medium in the word. The second context is when the /âa/ endures 'imāla when it is preceded by /i/, such as in imād. It is understandable in such a case to interpret imäla as a long front medium vowel /ê/, as the tongue takes the medium position to pronounce the short medium front vowel $/ \mathrm{i} /$ and remains at the same lower position to pronounce the long front vowel and raises it from its original low front position.

$J A I S \bullet 15$ (2015): 59-72 
(5) imād > imēd 'pillar'

Third, the /ā/ endures 'imāla when it is preceded by a long front high $/ \overline{\mathbf{1}} /$ vowel and a $/ \mathrm{h} /$, such is in the case of yakila-hā. It is acceptable in such a case to accept Owens onglide /ia/ explanation, as the tongue is raised to produce the front high long vowel $/ \overline{1} /$, colors the following short /a/ to make it an /e/ and starts the long final originally low front vowel from a higher tongue position than usual. This apparently is a case of 'imála from vowel harmony that the Arab grammarians called 'itb $\bar{a}$, where usually a contextual long vowel colors the rest of the short and long vowels of the word, provided of course that there is not a consonantal context of guttural sounds (Sībawayh, al-Kitāb, II: 259).

(6) yakīla-hā > yakīli-hia 'he weighs it'

'itbā' is a dialectal feature of the Tamīmi dialects ('Abū Hayyān, al-Bahrr, IV: 413). In all the examples of 'itb $\bar{a}^{c}$ in these works, the long front high vowel $/ \overline{1} /$ raises short and long preceding and following vowels in the word. It is also to be noticed that Sibawayh puts the condition that there must be a $/ \mathrm{h} /$ sound between the inclined vowel and the preceding long $/ \overline{1} /$. This condition seems also to be relevant to nouns followed by suffix pronouns, where imāla happens in the suffix long vowel as well as the stem vowels. And the examples Sībawayh and al-'Axfaš (Ma'ānīal-qur'ān, I: 13) give are in fact nouns followed by object suffix pronouns. Apart from the guttural consonant sounds, there is no phonetic preventative factor that may inhibit vowel harmony on all kinds of suffixes in Arabic, and not only object suffix pronouns. Nominal and suffixes in Arabic do not include any of these 'imāla-prohibiting sounds.

\section{Discussion}

The three previous realizations of imāla exist in the dialects of Tamīm. They are collectively labeled 'alif. Orthographically, they are represented by one letter with the same name. I would

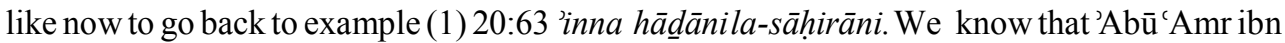
al-'Alä' read the verse with what the grammarians claimed to be $y \bar{a}$ ' and $n \bar{u} n$ as hädayni. One question is why did he do this despite the fact that his tribe Tamim treated the dual suffix invariably? Another question is why did he read the predicate with an ambiguous 'alif despite his Tamīmi origin that is supposed to have used 'imāla? If Tamīm did not decline the dual suffix for case as the grammarians claim, both the subject and the predicate must have been given the same dual suffix. But I claim that the similarity between the vowel behavior and case distinction in the subject that is governed by 'inna is only accidental. The /-ay/ reading of the first word $h \bar{a} \underline{d}$ ayni in the 'Abu ${ }^{C} \mathrm{Amr}$ ibn al-'Alā' reading is explainable not in terms of case differentiation as a dual accusative noun, but in phonetic terms. The same goes for the /-ān/ ending of the nominative predicate dual noun sāhirānn. Its long non-'imāla vowel is not case-based, but dictated by the phonetic environment.

The explanation of the seemingly nominative predicate sạhirān is that it does not seem to be in a state of 'imāla because there is before the long vowel, an imäla-repellent /r/ sound (Owens 2006: 199-201). The long vowel here stays as $/ \bar{a} /$ and does not go either into /ai/, /ia/ but may incline towards the tafxim vowel $/ \overline{0} /$. Phonetically, the first 
seemingly accusative noun hâdayni is a good example of the off-glide explanation explained above and in Owens (2006). In anticipation for the short /i/ at the end of the word, the tongue glides from a lower or a medium position to a higher position, thus producing /ai/glide sound. This example is identical to the example in (4) of the first phonetic contexts that Sỉbawayh provided for imäla, where the short /i/ follows the long vowel /ā/. This example and its reader 'Abū 'Amr ibn al-'Alä' are especially important to our purpose here because the token has an origin whose dialect is claimed to not decline dual suffixes for case and there is a clear phonetic explanation for the variable treatment of the suffix. This situation could justify the grammarians' perception and could have provided them for two forms of the dual suffix that they had to explain.

The same (1) token is also important from the point of view of the other readings. All the other readers from the rest of the pre-Islamic tribes treat the dual suffix in inna hādāni la-sāhhirāni invariably (Ibn al-Ǧazrī, an-Našr, II: 321). This means that all readers did not decline the dual suffix for case, and not only the Tamimi dialects. In the third context of Sibawayh, we can see that the vowel of the stem affects the long vowel in the suffix. It is, therefore, very plausible that the later re-interpretation of the different long vowel qualities led to the structured case relevance. But tokens of invariable duals in texts other than kaläm al-'arab are admittedly very few. The fact that two examples only from the Qur'ān and one mere example from Hadīt can be found to corroborate the grammarians' assumption that the pre-Islamic dialects did not decline the dual suffix for case comes from the possibility of the grammarians preferring other sources to kalam al-'arab in the standardization of the language in the $8^{\text {th }}$ century. The tokens of invariable dual suffix in pre-Islamic poetry are minimal if not non-existent. To standardize the dual suffix as a morpheme of two allomorphs, one for the nominatives and the other to accusative and genitive, the grammarians must have considered data from pre-Islamic poetry more trustworthy than that of kalām al-'arab, especially when it matches the dual suffix treatment in the Qur'ān.

\section{Conclusion}

Pre-Islamic dialects were one of the sources the grammarians depended on in standardizing Classical Arabic. Some of these dialects were more trustworthy than others and more confirmatory to the grammarians perceptions than others. The dialect group of Tamìm is one of those dialects. However, it seems that as far as the case marking on the dual suffix is concerned, Tamìm did not differentiate between the dual suffix in the nominative and in the accusative and genitive. We also know that Hijāz may have also not declined the dual for case. Understanding the declination of the dual suffix for case in Classical Arabic is problematic if we take the Arab grammarians' theoretical concept of $s a m \bar{a}^{`}$ to be governing and effective. According to this concept, trustworthy kaläm al-'arab is a source of data for the grammarians. Yet, Classical Arabic differentiates dual suffixes according to case. It seems to me, therefore, that the dialect of Tamīm did not exhibit case marking on all kinds of nominal endings. 


\section{References}

\section{Primary Sources}

'ABŪ ḤAYYĀN, Al-Bahrr al-Muhịt. Al-Riyadh: Maktabat wa-mațābi' an-nașr al-ḥadīt, 2008.

al-'AXfaš, Ma'ān̄̄ al-Qur'ān. Ed. Hudā Qurrāáa. Cairo: Maktabat al-Xānǧ̄i, 1990.

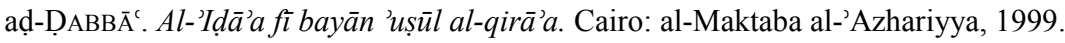

al-HamadĀNī. Șifat ğazīrat al-'arab. Ed. Muḥammad b. 'Alī al-'Akwa'. Șan'ầ': Maktabat al-'iršāa, 1990.

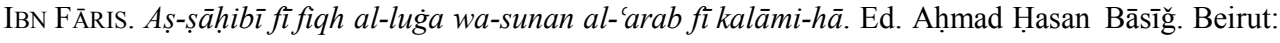
Dar al-kutub al-ilmiyya, 1997.

IBN al-ĞAZRĪ. An-našr fì al-qirā'āt al-'ašr. Ed. 'Alī Muhammad aḍ-Ḍabbā'. Cairo: al-Maṭba'a attiğāriyya, 1960.

IBN ĞInNī. Sirr șinā'at al-î́rāab. Ed. Hasan Hindāwī. Cairo: Dār al-kutub al-mișriyya, 1993.

IBN al-Ḥ̂̄̄̌̆IB. Šarh aš-šāfiya. Ed. Muḥȳ̄ ad-Dīn 'Abd al-Ḥamīd. Beirut: Dār al-Kutub al-'Tlmiyya, 1982.

IBN ḤAZM. Ğamharat 'ansāb al-'arab. Ed. 'Abd as-Salām Hārūn. Cairo: Dār al-ma'ārif, 1983.

IBN Hišs̄M. Muginnī al-Labīb 'an kutub al-’a'ārīb. Ed. Muḥammad Muḥȳi ad-Dīn 'Abd al-Ḥamīd. Cairo: Maṭba'at al-dadanī, 1990.

IBN XĀLAWAYH. Al-ḥuğğa fì 'l-qirā'āt as-sab'. Ed. 'Abd al-'Āl Sālim Makram. Cairo: Dār aš-šurūq, 1979.

IBN YA'Ǐš. Šarh al-mufașșal. Cairo: al-Maṭba'a an-nayriyya, 2001.

al-QALQAŠANDĪ. Nihāyat al-'arab fì márifat 'ansāb al-'arab. Ed. Ibrāhīm al-'Ibyārī. Beirut: Dār alkitāb al-lubnānī, 1980.

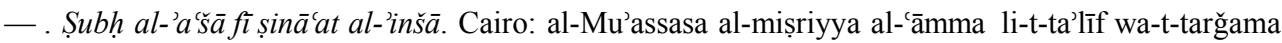
wa-n-našr, 1922.

as-SuYūṬī. Al-iqtirāh fì ilm 'ușūl an-naḥw. Haydar Abād: Dā’irat al-ma'ārifal-'uțāniyya, 2006.

—. Al-muzhir fì 'ulūm al-luġa wa-'anwāi $i$-hā. Eds. Muḥammad Aḥmad Ğād al-Mūlā, Muhammad 'Abū 'l-Fạ̣l Ibrāhīm and 'Alī Muhammad al-Bīğāwī. Cairo: Dār 'iḥyā' al-kutub al-'arabiyya, 1988.

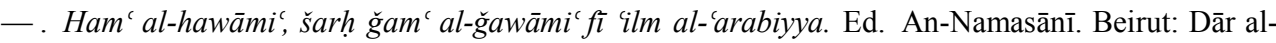
ma'rifa, 1990.

SīBAWAYH. Al-Kitāb. Ed. 'Abd as-Salām Hārūn. Cairo: al-Hay’a al-mișriyya al-āmmma li-t-ta'lîf wa-nnašr, 1955.

az-ZAMAXŠARĪ. Mufașsal fì n-naḥw. Ed. Maḥmūd Tawfīq, Cairo: Maṭba'at ḥiğāzīi, 1993.

\section{Secondary sources}

Al-Sharkawi, Muhammad. 2008. "Pre-Islamic Arabic". In: Encyclopedia of Arabic Language and Linguistics, ed. Kees VersteEGH, IV: 689-699. Brill, Leiden.

— . 2013. "The Development of the Dual Paradigm in Arabic". Al-'Arabiyya: Journal of the American Association of Teachers of Arabic, 43:1-22.

BAKALla, Muhammad Hasan. 2009. "tafxìm”. In: Encyclopedia of Arabic Language and Linguistics, ed. Kees VersteEGH, IV: 421-424. Brill, Leiden.

BennetT, Patrick. 1998. Comparative Semitic Linguistics: A Manual. Eisenbrauns, Winona Lake. 
CORRIENTE, Federico. 1977. A Grammatical Sketch of the Spanish Arabic Dialect Bundle. Instituto hispano-arabe de cultura, Madrid.

EDZARD, Lutz / RETSÖ, Jan (eds.). 2006. Current Issues in the Analysis of Semitic Grammar and Lexicon II. Harrassowitz, Wiesbaden.

FISCHER, Wolfdietrich. 2006. "Classical Arabic". In: Encyclopedia of Arabic Language and Linguistics, ed. Kees Versteegh, I: 397-411. Brill, Leiden.

Fontinoy, Charles. 1969. Le duel dans les langues semitiques. Paris: Société d’Édition "Les Belles Lettres".

Hasselbach, Rebecca. 2013. Case in Semitic: Role, Relations, and Reconstruction. Oxford: Oxford University Press.

LeTourneau, Mark. 2006. "Case Theory". In: Encyclopedia of Arabic Language and Linguistics, ed. Kees VersteEgh, I: 347-353. Brill, Leiden.

LEVIN, Aryeh. 2007. "imāla”. In: Encyclopedia of Arabic Language and Linguistics, ed. Kees VerSTEEGH, II: 311-314. Brill, Leiden.

LIPIŃSKI, Edward. 1997. Semitic Languages: Outline of a Comparative Grammar. Peeters, Leuven.

NEBES, Norbert. 1985. “in al-muhaffafa und al-lām al-fāriqa II”. Zeitschrift für arabische Linguistik, 14: 7-44.

Owens, Jonathan. 2006. A Linguistic History of Arabic. Oxford University Press, Oxford.

RABIN, Chaim. 1951. Ancient West-Arabian. Taylor's Foreign Press, London.

RETSÖ, Jan. 2006. "Thoughts about the Diversity of Arabic”. In: EDZARD/RETSÖ (eds.) 2006: 23-33.

SHAH, Mustafa. 2009. "qirā'āt". In: Encyclopedia of Arabic Language and Linguistics, ed. Kees VERSTEEGH, IV: 4-11. Brill, Leiden.

(C) MuHAmmad AL-SHARKAwI, Wayne State University, Detroit, USA

4 mohamed.el-sharkawi@wayne.edu 